work. Further details can be obtained from : Prof. A. Frey-Wyssling, Pflanzenphysiologisches Institut, Zurich; Dr. G. van Iterson, Baarn, Holland; or Dr. P. Eggleton, Physiology Department, University of Edinburgh.

\section{Summer Schools in Relaxation Methods}

Summer schools in relaxation methods were held in the Imperial College of Science and Technology, London, during the long vacations in 1945-8, and in the University of Michigan in 1949. Their success has encouraged the provision of similar courses in both Britain and the United States in the coming long vacation, and the programme will cover lectures and practice on the numerical solution of linear algebraic equations, framework problems, Laplace's and Poisson's equations, the biharmonic equation, eigen-value problems, the heat-conduction equation, etc. The course in Britain will be at the Imperial College of Science and Technology, South Kensington, London, S.W.7, during August 29September 22 ; the fee will be $\mathfrak{E 5}$, and further particulars can be obtained from D. N. de G. Allen at the Imperial College. In the United States the course will occupy six weeks in June and July at the Virginia Polytechnic Institute, Blacksburg, Va., and inquiries should be addressed there to Prof. D. H. Pletta.

\section{University of London: Appointments}

THE following appointments in the University of London have been announced: Dr. E. K. Rideal, lately director of the Davy Faraday Research Laboratory and Fullerian professor of chemistry in the Royal Institution, to the University chair of chemistry tenable at King's College, from August 1, 1950 ; Dr. H. J. Eysenck, to the University readership in psychology with special reference to psychiatry tenable at the Institute of Psychiatry, from February 1,1950 .

\section{University of Leeds: Appointments}

THE following appointments have recently been made in the University of Leeds : Dr. F. W. Spiers, lecturer in medical physics in the Department of Radiology and Radiotherapy, to the newly instituted chair of medical physics; Dr. N. H. Hartshorne, lecturer in chemical microscopy, to be reader in chemicel microscopy; Mrs. Georgiana M. Bonser and Dr. L. L. Dmochowski, lecturers in the Department of Experimental Pathology and Cancer Research, to be readers in cancer research.

\section{University of Sheffield}

UNDER the terms of the will of the late Prof. D. Knoop, professor of economics in the University of Sheffield during 1920-48, the residue of his estate was left to the University to be used for the promotion of the study of economics and economic history. With this object in view, the University Council has established Douglas Knoop research fellowships (£425 a year) and the Douglas Knoop research studentships ( $£ 300$ a year), in economics and economic history. It is hoped that appointments will be made in time for the new Fellows or Students to take up residence in October of this year. The West Riding County Council has made an additional grant of $£ 1,500$ a year to the University to further the study of microbiology and in particular towards the chief lectureship in this subject in the University. The title of emeritus professor has been conferred upon Dr. B. M. Laing, who retired from the chair of philosophy at the end of last session. Dr. S. E. Dicker has been appointed lecturer in physiology in the University.

\section{Iron and Steel Institute : Medals and Prizes}

THE Iron and Steel Institute has recently awarded the following medals and prizes : Bessemer Medal for 1950, to Mr. James Mitchell (honorary treasurer, Stewarts and Lloyds, Ltd.), in recognition of his distinguished contributions to the technical development of the iron. and steel industry; Sir Robert Hadfield Medal for 1950, to Mr. G. D. Elliot (ApplebyFrodingham Steel Co., Scunthorpe), in recognition of his contributions in practice and theory to the development of blast-furnace operation; A Carnegie Silver Medal for 1949, to Mr. N. H. Polakowski (University College, Swansea), for his Andrew Carnegie research report on "The Compression Test in Relation to Cold Rolling" ; Williams Prize for 1949, jointly to Dr. D. F. Marshall and Mr. H. C. White (Park Gate Iron and Steel Co., Ltd., Rotherham), for their paper on "The Conversion to Oil Firing of the Open-Hearth Furnace at Park Gate Works"; Ablett Prize for 1949, jointly to Mr. E. L. Diamond (British Standards Institution; formerly British Iron and Steel Research Association, London) and Mr. A. M. Frankau (British Iron and Steel Research Association, London), for their paper on "Present Methods of Open-Hearth Furnace Charging".

\section{Announcements}

WE regret to announce the death on March 18, at the age of sixty-six, of Sir Norman Heworth, F.R.S., lately professor of chemistry and director of the Chemistry Department in the University of Birmingham.

THE title of emeritus professor in the University of Durham has been conferred on Prof. David Burns, recently professor of physiology in King's College, Newcastle upon Tyne (University of Durham).

THE title of emeritus professor in the University of Birmingham has been conferred on Prof. G. Haswell Wilson, formerly professor of pathology, and Prof. L. J. Wills, formerly professor of geology and mineralogy. The following appointments in the University have also been announced: Mr. S. Marchant to be lecturer in geology, and Dr. R. L. Whitmore to be lecturer in coal treatment.

Dr. Ivor IsAaC and Mr. G. T. Goodman have been appointed lecturer in botany and assistant lecturer in botany respectively in the University College of Swansea:

THE Surgeon-General of the U.S. Army has announced that it has been decided to discontinue the "Index-Catalogue of the Library of the SurgeonGeneral's Office".

The third Conference on the Education of the Young Worker will be held in Magdalen College, Oxford, during August 12-18. The main subject of investigation and discussion will be "The Young Worker in the Job: Initial and Continuing Education". Further information can be obtained from the Director, University Department of Education, 15 Norham Gardens, Oxford.

ERratuM.--In the communication on the photodegradation of starch by Frank Baker and W. J. Whelan in Nature of March 18, p. 449, the wavelength of light used was $2537 \mathrm{~A}$., not $3660 \mathrm{~A}$. as printed. 